\title{
A KAVARÓ DÖRZSHEGESZTÉS ALKALMAZÁSI LEHETŐSÉGEI ALUMÍNIUM KOMPOZITOK ESETÉN
}

\section{APPLICATION OF FRICTION STIR WELDING IN CASE OF ALUMINUM COMPOSITES}

\author{
Kovács Zsolt Ferenc ${ }^{1^{*}}$, Hareancz Ferenc ${ }^{1}$ \\ ${ }^{1}$ Innovatív Jármüvek és Anyagok Tanszék, GAMF Müszaki és Informatikai Kar, \\ Neumann János Egyetem, Magyarország \\ https://doi.org/10.47833/2021.1.ENG.011
}

\section{Kulcsszavak: \\ kavaró dörzshegesztés \\ vegyes kötés \\ alumínium kompozit \\ hegesztés \\ metallográfia \\ Keywords: \\ friction stir welding \\ dissimilar joint \\ aluminium composite \\ welding \\ metallographic}

\section{Cikktörténet:}

Beérkezett 2021. március 10.

Átdolgozva 2021. április 15.

Elfogadva 2021. április 20.

\begin{abstract}
Összefoglalás
Az ipar folyamatosan fejlődik, így újabbnál újabb anyagösszetételekkel és felhasználási módszerekkel találkozhatunk. Ahhoz, hogy ezeket az újitásokat szélesebb körben is tudjuk alkalmazni, folyamatosan kutatnunk kell a hegesztési eljárások határait. Ezen cikk egy viszonylag új kötési eljárást mutatunk be különböző alumínium ötvözetek és kerámia szemcsés kompozitok alkalmazásával. Az eljárás neve angolul Friction Stir Welding (FSW), magyarul kavaró dörzshegesztés. A cikkben röviden ismertetésre kerül a kavaró dörzshegesztés és annak alkalmazása. A hegesztések elvégzése után a darabokon metallográfiai és keménységmérési vizsgálatokkal minősítettük.

Abstract

The industry is constantly evolving, so we can meet newer and newer material compositions and applications. To these innovations can be applied more widely, we must constantly explore the welding procedures. This article presents a relatively new welding procedure using various al-uminium alloys and ceramic granular composites. The procedure is Friction Stir Welding (FSW). This article briefly introduces FSW procedure and its application. After welding, the pieces were subjected to metallographic and hardness tests.
\end{abstract}

\section{Bevezetés}

A dörzshegesztés során akár két különböző mechanikai tulajdonságú, eltérő anyagú munkadarabok egyesítése is megvalósítható, ami más hegesztő eljárással nem lehetséges [1][2][3]. A kavaró dörzshegesztést (43-as kódú eljárás) 1993-ban a NASA is elkezdte használni ezt a fajta hegesztési eljárást a projektjeihez, kezdetekben lágy anyagok egyesítésére alkalmazták, föleg alumínium és ötvözeteire, de mára gyakorlatilag bármely anyag egyesíthető ezzel az eljárással [4][5].

A legtöbb dörzshegesztő eljárással ellentétben, itt a kötést egy dörzshegesztő szerszám segítségével valósítjuk meg. Magát a szerszámot általában egy váll és egy tű alkotja, de polimereknél az előbbit egy burkolattal szokták helyettesíteni vagy egy hegesztőpapuccsal egészítik ki, ami kutatások alapján meglehetősen hatékony megoldásnak bizonyul [4-10].

\footnotetext{
* Kapcsolattartó szerző. Tel.: +36 123456 789; fax: +36 987654321

E-mail cím: f.a.author@institu.te
} 
A szerszámot adott fordulatszámmal forgatva, oldalról vagy felülröl belevezetjük az anyagba úgy, hogy a váll felfeküdjön a lemezek felületére. A darabok a súrlódási hőnek köszönhetően meglágyulnak, de soha nem érik el az olvadáspontot, utána a szerszám egy adott elötolással el kezd haladni, összekeverve a két anyagot. A szerszám és a lemezek között súrlódás okozta hő lép fel, ami az anyag képlékeny alakítását teszi lehetővé. A keverés során az anyag igyekszik felfelé távozni, amit a váll sajtoló ereje akadályoz, ezzel nyomást hozva létre az anyagban. A hegesztés folyamatot az 1. ábra szemlélteti [4-8].
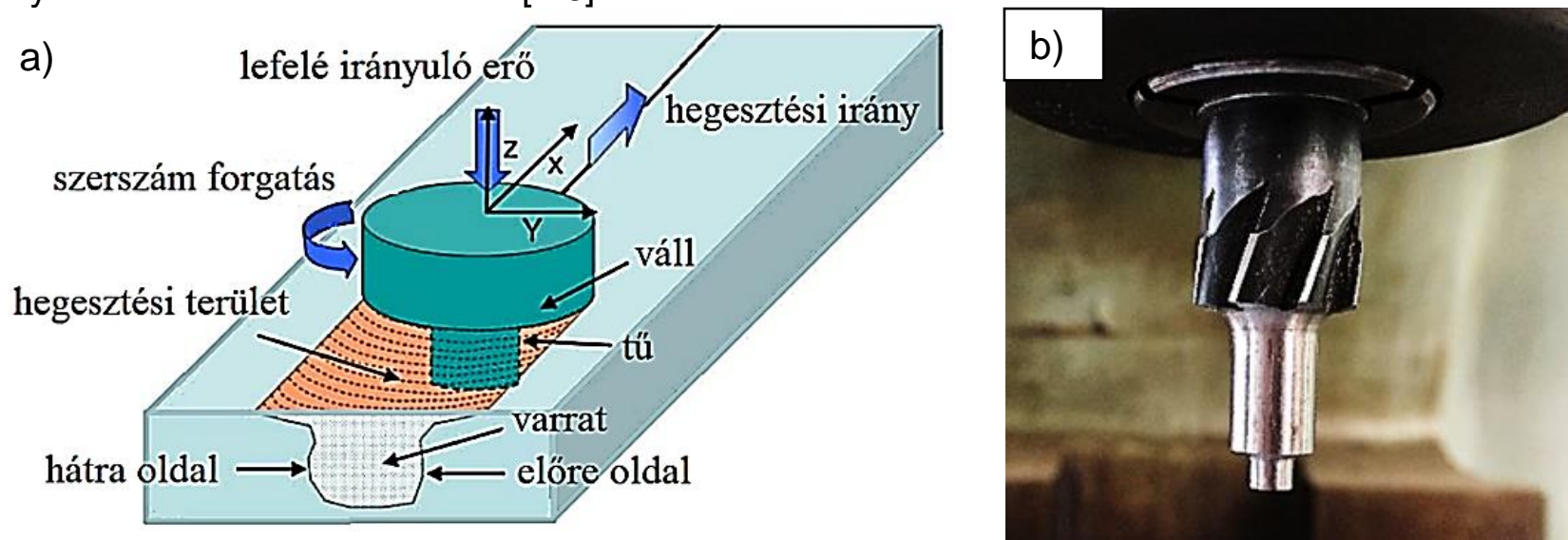

1. ábra A kavaró dörzshegesztés a) elvi ábrája [2] és b) szerszáma

\section{Kísérlet ismertetése}

\subsection{Vizsgált anyag tulajdonságai}

A kísérletekhez C355 jelü különleges, kerámia szemcsékkel (Al2O3) erősített, alumínium kompozitot használtunk. A hegesztés elött a darabok anyagösszetételének pontos értékét FOUNDRY MASTER PRO típusú spektrométer segítségével határoztuk meg (1. táblázat).

1. táblázat. Vizsgált alapanyag összetétele

\begin{tabular}{|c|c|c|c|c|c|c|}
\hline Anyagjel & Al (\%) & Si (\%) & Cu (\%) & Mg (\%) & Cr (\%) & Ti (\%) \\
\hline C355 & $91,7-94,1$ & $4,5-5,5$ & $1,0-1,5$ & $0,4-0,6$ & 0,04 & 0,15 \\
\hline
\end{tabular}

A C355 alumínium kompozit összetételének érdekessége, hogy 1,0-1,5\% réz tartalma van, ami jelentősen növeli a szilárdságot, szívósságot, keménységet, viszont csökkenti a korrózióállóságot és rontja a hegeszthetőséget.

\subsection{Alkalmazott szerszám}

A szerszám anyaga alumínium munkadarab esetén HSS, így egy ujjmaróból készítettük el a szerszámot. A szerszám tủ átmérője egyenlő a lemezvastagsággal ( $\mathrm{s}=4 \mathrm{~mm})$, továbbá a hossza 3,7 $\mathrm{mm}$-re terveztünk, figyelembe véve a szakirodalmak által javasolt 8-10\%-al való csökkentést. $A$ váll szélességét irodalom kutatás alapján $12 \mathrm{~mm}$-re készítettük, mert vékony lemezeknél nem ritka, hogy a váll szélessége háromszorosa a lemezvastagságnak [4-10]. Az elkészült szer-szám képe a 1. b) ábrán látható.

\subsection{Munkadarab rögzítése}

A munkadarabok rögzítése fontos tényező a hegesztés szempontjából. Ha ez nem történik meg megfelelöen, akkor a kötés minősége nem biztos, hogy kielégítő lesz, legrosszabb esetben balesetet okozhat. A munkadarab és a gép asztala közé egy márványlapot helyeztünk, mellyel a hőelvonást megakadályoztuk, a gép asztala valamint a munkadarabok között. A leszorítást a 2. ábra szemlélteti. 


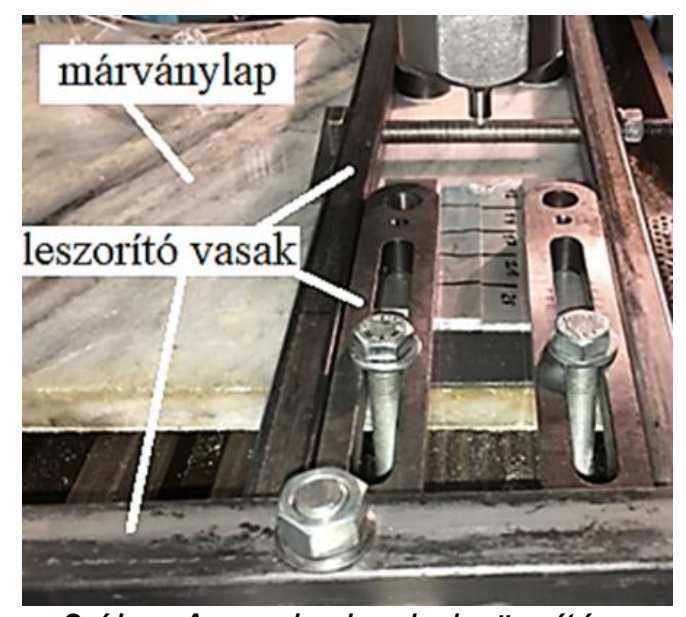

2.ábra A munkadarabok rögzítése

\subsection{Technológiai paraméterek}

A hegesztés során argon védőgázt használtunk, a szerszámot $3^{\circ}$-al bedöntöttük az előtolás irányába és a mintákat tompán illesztettük egymáshoz. A kísérlet során alkalmazott technológiai paramétereket a 2. táblázat tartalmazza.

2. Táblázat. Technológiai paraméterek

\begin{tabular}{|c|c|}
\hline Paraméter & Érték \\
\hline Fordulatszám (ford./min) & 950 \\
\hline Elötolás (mm/min) & $10 ; 15 ; 20 ; 25 ; 30 ; 35,40$ \\
\hline
\end{tabular}

\section{3 Eredmények}

A kísérletek során bizonyosságot szereztünk afelöl, hogy az argon védőgáz csupán hütötte a mintákat és a szerszámot, ami pozitívan hatott a hegesztésre. A sikeresen elkészült varratokból csiszolatok készültek, melyeket mikroszkóppal (3. ábra) és mikrokeménység (4. ábra) méréssel vizsgáltunk. A csiszolatokat Keller-féle maratószerrel 10-20 másodpercig marattuk.
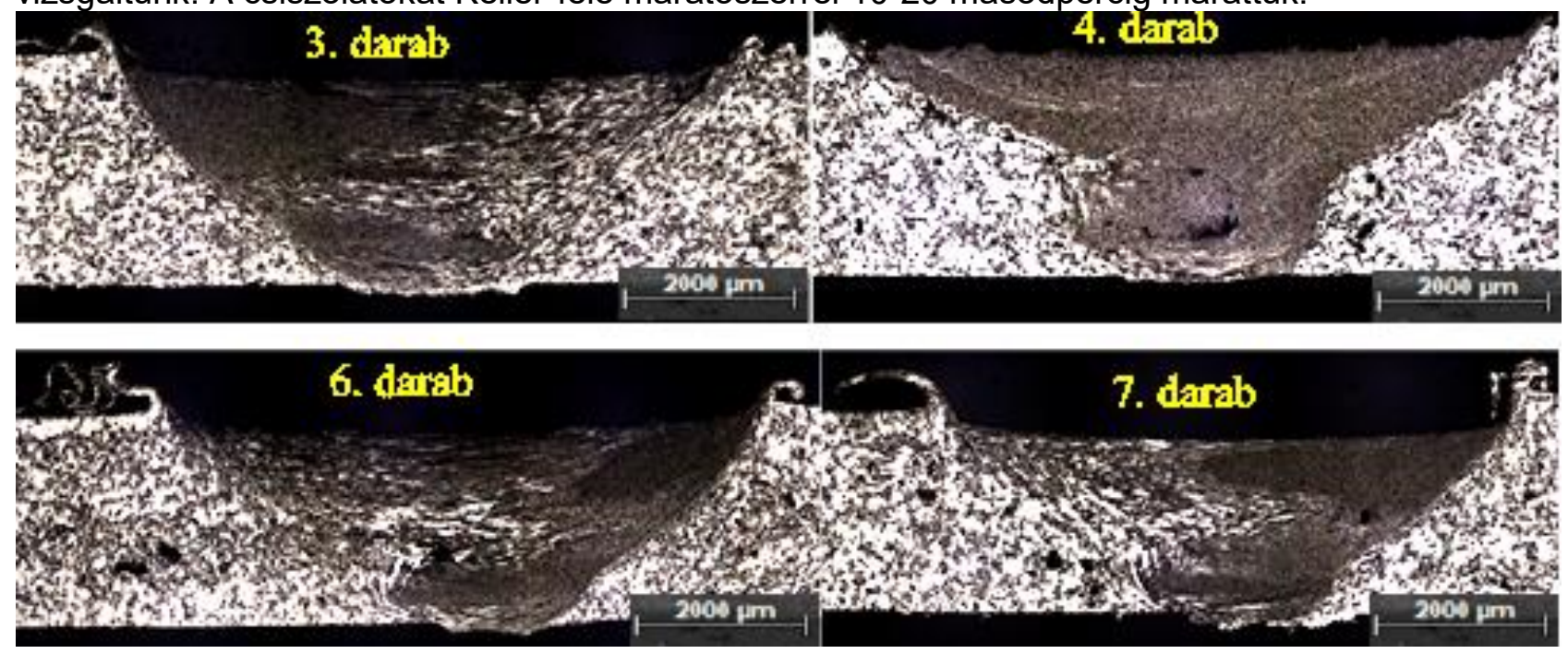

3. ábra. A harmadik, negyedik, hatodik és hetedik minták mikroszkópi kép

A keménységmérésböl következik, hogy a hőhatás övezetben az anyag keménysége $~ 45$ HV0,1 mindegyik mintánál (az alap fém keménysége 55 HV0,1). Ezen kívül az is látszik, hogy a varrathoz közeledve, illetve a varraton belül megnövekszik a keménység $\sim 30 \%$-al. 


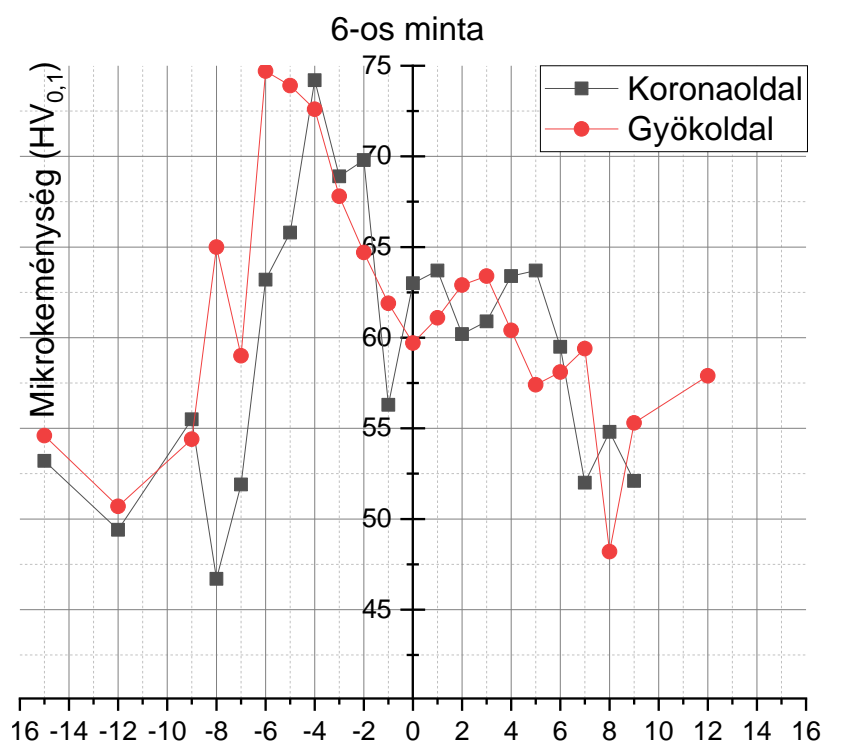

Távolság varratközéptöl $(\mathrm{mm})$

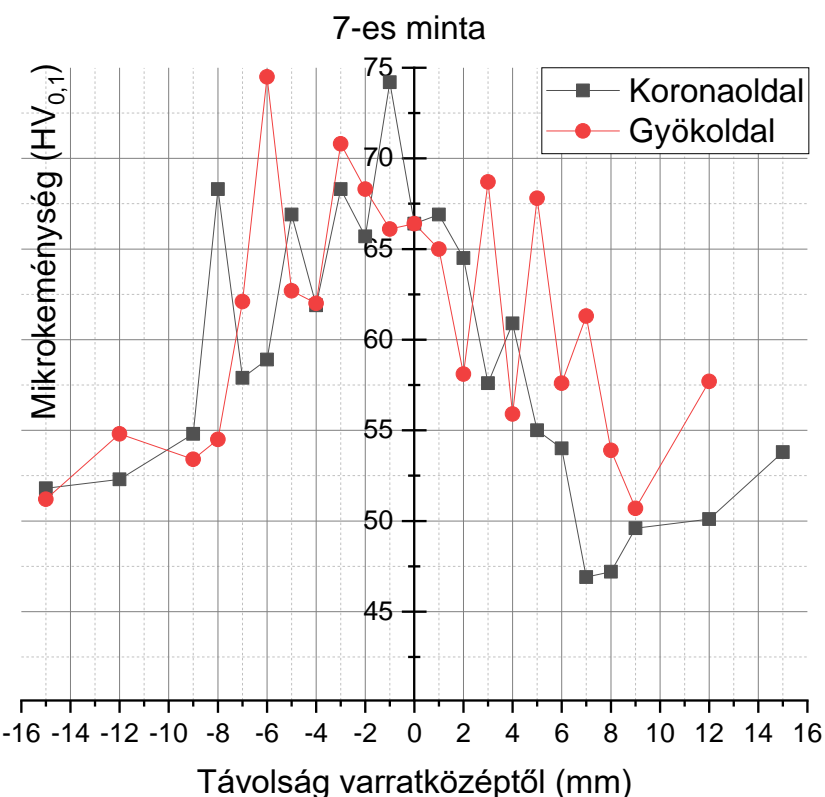

Távolság varratközéptől $(\mathrm{mm})$

4.ábra A hatodik és hetedik minta keménységmérési eredménye

\section{4. Összefoglalás}

A mikroszkópi képek és a keménységmérés eredményei alapján kijelenthető, hogy az FSW hegesztési eljárás alkalmas C355 alumínium kompozitok hegesztésére. Továbbá az alábbi eredményeket értük el:

- $20 \mathrm{~mm} / \mathrm{min}$-es elötolás alatt a varratok szemrevételezéssel is selejtnek bizonyultak

- az elötolás növelése javította a kialakult kötés minőségét

- az argon védőgáz alkalmazása nagymértékben növelte a varratok minőségét, mert a szerszámot és a munkadarab is hütését

- a C355 alumínium kompozit keményéges FSW hegesztéskor a varratközépben $\sim 30 \%$-al keményebb, mint az alapfém keménysége

Az elért eredmények alapján további kutatásaink során vizsgálni kívánjuk más hűtési eljárások hatását az FSW eljárásra. Emelet a technológiai paraméterek célszerü optimalizálását és a paraméterek hatását is megszeretnénk határozni.

\section{Köszönetnyilvánítás}

Köszönettel tartozunk a kutatás támogatásáért, amely az EFOP-3.6.1-16-2016-00006 „A kutatási potenciál fejlesztése és bővítése a Neumann János Egyetemen” pályázat kereté-ben valósult meg. A projekt a Magyar Állam és az Európai Unió támogatásával, az Európai Szociális Alap társfinanszírozásával, a Széchenyi 2020 program keretében valósul meg. A kutatást részben "Kutatások az ipari digitalizáció által nyújtott potenciál minőségi kiaknázására" című ED_18-2-20180006 támogatás tette lehetővé.

\section{Irodalomjegyzék}

[1] Dr. Gáti József: Hegesztési Zsebkönyv, Miskolc, 2013

[2] Dr. Baránszky-Jób Imre: Hegesztési Kézikönyv, Műszaki Könyvkiadó, Budapest, 1985

[3] Dr. Szunyogh László: Hegesztés és rokon technológiák Kézikönyv, Gépipari Tudományos Egyesület, Budapest, 2007

[4] Prof. Bharat Raj Singh: A Hand Book on Friction Stir Welding, 2012. ISBN10 $365910762 X$

[5] R.S. Mishra, Z.Y. Ma.: Friction stir welding and processing, Materials Science and Engineering: R: Reports Vol. 50, Issues 1-2, 2005, pp. 1-78. https://doi.org/10.1016/j.mser.2005.07.001 
[6] P. L. Threadgill és mtsai. Friction stir welding of aluminium alloys, International Materials Reviews, Volume 54 No 2, 2009, pp. 49-93. https://doi.org/10.1179/174328009X411136

[7] Gene Mather:. The welding of aluminium and its alloys, Woodhead Publishing Limited, Cambridge England, 2002, pp. 116-166. eBook ISBN: 9781855737631

[8] Kiss Zoltán: Vékony polimer lemezek kavaró dörzshegesztése, Hegesztéstechnika, XXVI. évfolyam 2015. 2. szám, old.: 33-36

[9] Y. N. Zhang, X. Cao, S. Larose and P. Wanjara: Review of tools for friction stir welding and processing, Canadian Metallurgical Quarterly, Vol. 51, No 3, pp. 250-261. https://doi.org/10.1179/1879139512Y.0000000015

[10] Ákos Meilinger, Imre Török: The importance of friction stir welding tool, Production Processes and Systems, Vol. 6, No 1, 2013, pp. 25-34 